IDS Sexuality and Development Programme

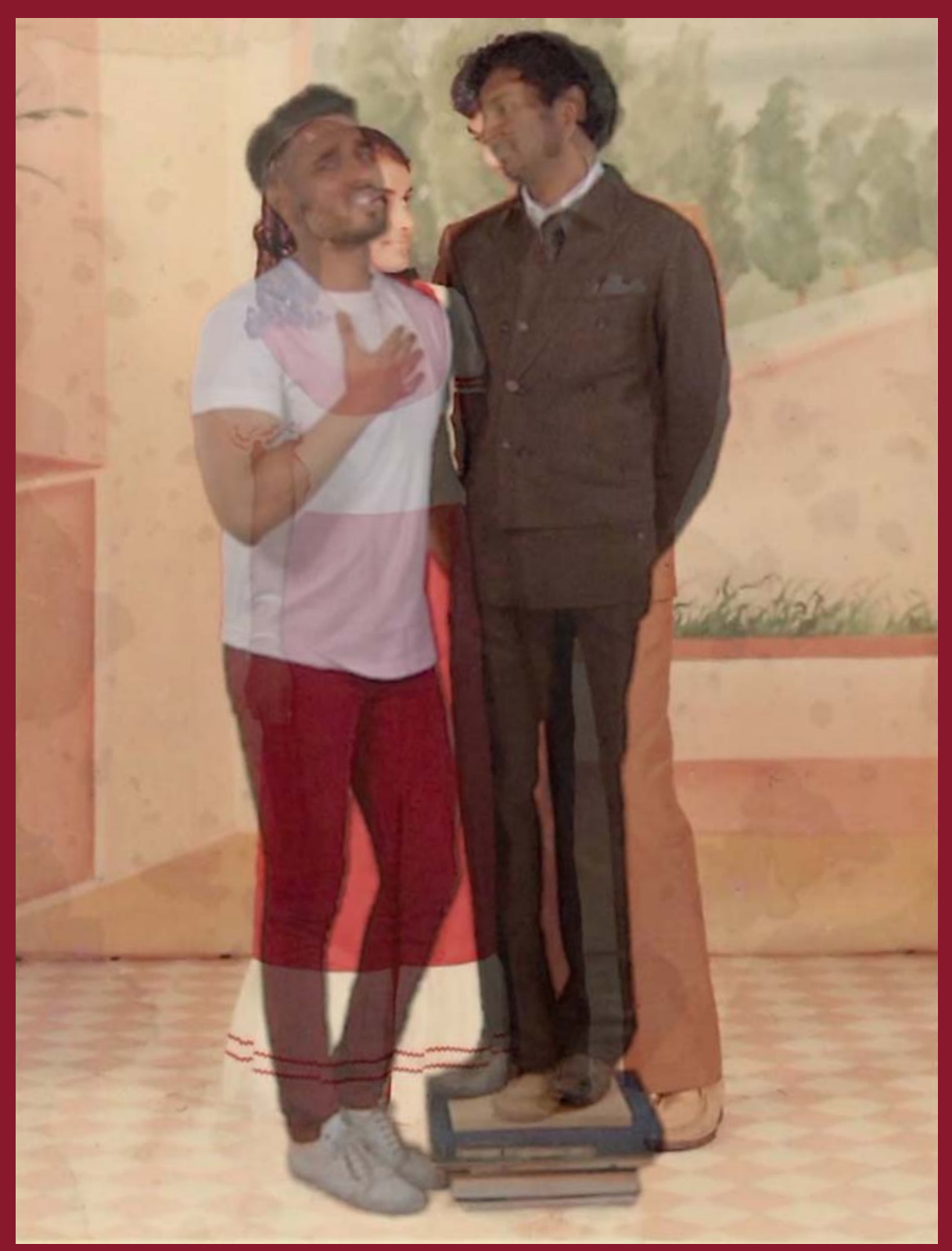

\title{
Rescue, and Real Love \\ Same-sex Desire in International Development
}




\section{About the IDS Sexuality and Development Programme}

The IDS Sexuality and Development Programme aims to achieve significant reductions in human rights violations, poverty and marginalisation through more effective development policy and practice that responds to the needs of people marginalised because of their sexuality. We undertake and support research and communications aimed at rethinking the relationship between sexuality, rights and development by building stronger links between people in different contexts working to realise their sexual rights. Working closely with established networks and movements around the world, our participatory approaches to protecting and respecting rights are based upon strategies drawn from local communities that are most affected.

To learn more about our work see: www.ids.ac.uk/idsresearch/sexuality and subscribe to receive our regular blog posts at www.ids.ac.uk/team/gender-and-sexuality.

\section{About the author}

Andil Gosine is Associate Professor in Liberal Arts and Professional Studies at York University, Toronto, and an artist. His previous publications include Sex for Pleasure, Rights to Participation, and Alternatives to AIDS: Placing Sexual Minorities and/or Dissidents in Development, IDS Working Paper 228, Brighton: IDS. 


\title{
Rescue, and Real Love. Same-sex Desire in International Development
}

\author{
Andil Gosine \\ IDS Sexuality and Development Programme
}

March 2015 


\section{Contents}

Introduction 3

Rescue 4

Real love $\quad 10$

A call for complexity $\quad 15$

Notes 17

References 18

\section{Acknowledgement}

We are particularly grateful to the Swedish International Development Cooperation Agency (Sida) for supporting the IDS Sexuality and Development Programme and for their contribution to printing and distribution costs through the IDS Gender, Power and Sexuality Programme.

\section{Abbreviations}

CAISO Coalition Advocating for Inclusion of Sexual Orientation (Trinidad and Tobago)

COC Cultur en Ontspanningscentrum/Center for Culture and Leisure (Netherlands)

IDS Institute of Development Studies

IGLHRC International Gay \& Lesbian Human Rights Commission

IPC Indian Penal Code

IMF International Monetary Fund

LGBT lesbian, gay, bisexual and transgender

LGBTI lesbian, gay, bisexual, transgendered and intersex

LGBTIQ lesbian, gay, bisexual, transgender, intersex and queer

LGBTQ lesbian, gay, bisexual, transgender and queer

NGO non-governmental organisation

RFSL Riksförbundet för homosexuellas, bisexuellas och transpersoners rättigheter/Federation for Lesbian, Gay, Bisexual and Transgender Rights (Sweden) 


\section{Introduction}

Fifteen years ago, I found little room in international development to talk about sexual desire or diversity. In all of the undergraduate classes I attended at my Liberal Arts college in Canada, and in all the graduate courses I attended at the Institute of Development Studies (IDS) in the UK, and at all the talks and seminars I went to in other places up to that point, never did anyone stray from the characterisation of Third World peoples as universally heterosexual. Never did any teacher or policymaker that I encountered seem aware that among development's 'poor' might be some people not fully committed to heterosexual procreation. Instead, we were encouraged to think of the 'world's poor' as masses of men and women whose reproductive choices were governed not by anyone's individual desires, but entirely a consequence of social, economic and cultural factors. Ten years ago, my supervisor at the World Bank, Agricultural Economist Hans Binswanger, did what many others in the field were doing at the time - he seized upon openings made available by fears about HIV and AIDS to incite broader conversations about sexual violence and sexual rights, particularly for people not uniquely engaged in heterosexual relationships. When Binswanger and I spoke at a forum on 'Sexuality and Development' in 2006 - a first inside the Bank - there was a great deal of concern about how many and who would come, and what kind of backlash might ensue (Gosine 2010b). But when another such forum was staged in 2014, no such worries circulated. High-ranking officials from across all regions came, and the World Bank President, Jim Yong Kim, himself was expected to join. It was rumored that Kim cancelled his planned appearance due to some tensions within the Bank hierarchy about his decision to put a $\$ 90$ million loan to Uganda on hold because that country's parliament had recently passed more punitive laws criminalising homosexuality. Making his case in the Washington Post, Kim noted, 'Institutionalized discrimination is bad for people and for societies. Widespread discrimination is also bad for economies. There is clear evidence that when societies enact laws that prevent productive people from fully participating in the workforce, economies suffer' (Kim 2014).

In 15 years, we have moved from almost complete disavowal of homosexuality in international development ${ }^{1}$ to the advocacy of sexual minority protection rights by the industry's ${ }^{2}$ most powerful multilateral institution and champion of neoliberal capitalism. There is now a considerable body of work that documents and which itself has contributed to the growing attention to and normalisation of same-sex desire in development (Adams and Pigg 2005; Bedford 2009; Cornwall, Correa and Jolly 2008; Cornwall and Jolly 2009; Gosine 2004, 2010a, 2010b; Murray 2009; Lind 2010; Oswin 2007). These studies reveal how anxieties about HIV and AIDS, as well as major sexual rights' victories in Western European and North American metropolis, challenged heteronormativity in development. For example, many development workers began to identify and organise themselves as queer subjects, with lesbian, gay, bisexual and transgender (LGBT) staff associations being established first at the World Bank, in 1993, and later at the International Monetary Fund (IMF) and the United Nations (Gosine 2010a). Donors like the Swedish International Development Cooperation Agency (Sida) also formally identified 'sexuality' as a development funding priority, and in 2011 then Secretary of State Hillary Clinton established the Global Equality Fund to support programmes that advance the human rights of LGBT people around the world. Organisations like Human Rights Watch, Hivos and Amnesty International focused new attention on sexual rights' abuses in developing countries and new groups also emerged, like the Canada-based not-for-profit ARC International. The recent expressions of interest in the wellbeing of gays and lesbians by even representatives of the industry's more conservative players, like Kim, are also undoubtedly linked to victories by same-sex rights advocates, especially in the United States, and rising global awareness and reach of 'gay' identity and culture.

The matter of recognition and rights for people engaged in same-sex relationships is far from settled. The journey of legal struggles over challenges to India's anti-sodomy legislation is telling of this volatile dynamic. A New Delhi High Court ruled the laws 'unconstitutional' in July 2009, but in 
December 2013, India's Supreme Court overturned their ruling, leaving it to Parliament to craft a new law. The 2014 victory of an unsympathetic, right-wing national government leaves human rights activists with little hope for such a change; they are appealing the ruling through India's courts. The election of a socially conservative majority in Brazil's Congress in 2014 similarly threatens recently legislated protections afforded to sexual minorities and rights to same-sex marriage. In many other countries, severe discriminatory laws against people expressive of same-sex desire continue to exist, and many are punitively deployed. But it is also clear that within the development industry, there has been a dramatic turn in the last 15 years, and over the last decade especially. How do we make sense of and what do we make of this massive shift? Should we view Kim's intervention, among others, as indication of ongoing 'progress' on sexuality rights? Do we celebrate the greater interest in the lives and wellbeing of people engaged in same-sex relationships by development organisations like Sida, the formation of sexuality-focused organisations like ARC International, and transnational interest by LGBT groups based in the North, in supporting rights of LGBT people in the South? In this paper, I suggest a more cautious and critical reading of the newfound enthusiasm to 'rescue' LGBT people in Global South countries, and call for greater recognition of and respect for the complexly lived sexualities of the 'world's poor'. I lay out the fuller contexts in which imperatives to 'rescue' LBGT people must be considered, and discuss some of their limitations and consequences. I also propose and explain my preference to speak about what I call 'real love' rather than sex, in an attempt to both broaden and deepen comprehension of 'desire' in development, and to restore and underline the humanity of development's primary subjects, the ones called 'the poor'.

\section{Rescue}

There is now considerable interest in and resources extended toward the rescue of nonheterosexual people from homophobia in Global South countries. State initiatives include Sida's sexuality-themed programme and the US Global Equality Fund, while support from multilateral institutions has come not just in the form of newspaper editorials, but also motions against violence based on sexual orientation, by the United Nations' General Assembly in 2011 and 2014 , and the hiring of economist Lee Badgett by the World Bank to 'cost' the impact of homophobia in India. International non-governmental organisations (NGOs) like Human Rights Watch, Hivos and Amnesty International pursue the cause of LGBT rights in many countries around the world, including Egypt, Kenya, Uganda, Indonesia, Gambia, Malaysia, South Africa and Brazil. National LGBT organisations have also become engaged in international development programmes in the past decade, such as Sweden's RFSL (Riksförbundet för homosexuellas, bisexuellas och transpersoners rättigheter/Federation for Lesbian, Gay, Bisexual and Transgender Rights) and the COC Netherlands (Cultuur en Ontspanningscentrum/Center for Culture and Leisure). What underlies the imperative of these groups to rescue, and what are the consequences of enacting 'rescue' of LGBT people?

Surveys have recorded gradual shifts in public opinion over attitudes toward homosexual rights and gay marriage in many different parts of the world. ${ }^{3}$ This shift has usually been attributed to the victorious efforts of LGBT advocates in winning support for their cause, and more often to the general progress of modernity. However, Jasbir Puar and Joseph Massad offer alternate and more complicated explanations for shifting views on particular sexual rights. Puar is best known for her coining of the term 'homonationalism' to characterise the process whereby some 'queer' bodies are folded into the nation-state and achieve citizen-consumer membership through consumerism, economic mobility, and the securing of individual rights, such as gay marriage, at the expense of others, and of structural change that challenges institutional heteronormativity (Puar 2007). Puar's framework pushes us to think about the gains and losses incurred in the identification and pursuit 
of certain kinds of sexual rights, especially same-sex marriage, and the context in which they occur. In Terrorist Assemblages (ibid.), she links rising support for same-sex marriage in the USA with its military response to the 9/11 attacks on the World Trade Center and wars in Iraq and Afghanistan, and argues that queer bodies are being used to incite and support racialised violence. Massad makes a similar kind of claim in his critique of what he terms the 'Gay International'. He views the work of LGBT organisations engaged in North-South transnational advocacy as an attempt to fulfil Western imperialism's unfinished tasks. In the Middle East, this Gay International lobby, Massad says, proposes that Arabic societies become educated to 'catch up' to metropolitan Euro-American norms: 'They must take on sexual identities, name themselves "gay" and "lesbian" (as conferred, for instance, by the "Gay and Lesbian Arabic Society"), mimicking the more enlightened and civilized Occident' (Massad 2007: 173).

However well-intentioned development efforts to support LGBT rights in the Global South may appear to be, and however welcome they are by some LGBT-identified people in host countries, they must be weighed against Puar's and Massad's critiques. For instance, while development interventions by North-based organisations are usually pitched as helping hands to the South, it is important to recognise that these interventions have tended to first serve the 'helpers' themselves. LGBT activists from the Global North have made beautiful, and probably sincere, claims about their investments in rescue of same-sex desiring kin in the Global South. But this mission is hardly selfless. Consider the work of RFSL and COC, the two longest-existing LGBT organisations in the world. In a section on its website entitled 'Fighting for Acceptance All Over the World', COC explains:

Together, we fight for human rights for LGBT's [sic] all over the world and we counter those who oppose LGBT rights, groups that have become stronger and more organized over the last years. Although LGBT's [sic] in many countries suffer from discrimination and lack of equal rights, the situation in some parts of the world is extremely serious: pride manifestations are prohibited or violently attacked without police protection, prosecution, rape, murder, death penalties and other violations of basic human rights [sic].

(COC n.d.)

RFSL's 2008-2010 International Strategy similarly noted:

LGBT persons are daily subjected to persecution and discrimination all over the world. Homosexuality is criminal in 85 countries and punishable by death in seven. Discrimination, insulting treatment, harassment, assault, 'conversion' rapes, forced marriages, dismissal from work, outing in the media, and murder are examples of what the persecution of LGBT persons can lead to. In many countries, not even the most basic human rights are respected, and LGBT persons are forced to deny themselves and their lives in order to survive. Furthermore, the negative attitudes of their surroundings force LGBT persons to commit suicide or work in the sex industry against their wills.

(RFSL 2008)

These characterisations lead to a bold claim: 'this is something that RFSL can never accept' (ibid.). As a testament of their work, both groups are based in countries usually held up as exemplary champions of the sexual rights of gays and lesbians. Sweden was one of the first countries to recognise legal 'partnership' rights for gay couples, in 1995, and to extend adoption rights to samesex couples, in 2002; and in 2009, full marriage rights were approved by its parliament. The Dutch parliament granted same-sex couples domestic partnership benefits in 1998, and in 2001, the Netherlands became the first country in the world to legally recognise same-sex marriage. Faced with this sense of fait accompli, looking beyond their national boundaries has therefore served as one powerful justification for their continued existence to members and funders. Their adoption of international platforms opened up new sources of revenue; it has also offered justification for their continued existence. RFSL and COC access supporting funds from their national governments, the 
European Union and other donor agencies to carry out development projects in the Global South. COC Netherlands was first, its interest in international work spurred by cuts to institutional civil society funding by the Dutch government in 1989. COC Director of Programmes, Pieter Boone, explained the trajectory of the organisation's work in an interview with me in 2009 held at their Amsterdam office:

Our organisation had to transform into a project organisation. [After a short period during which time COC] didn't do a lot. Eventually, the movement realised we could actually formulate a project proposal, get money and use that money to subsidise our political activities. That is when we started to realise there was also funding for international work. [There was] 'no thought behind it, [no] 'let's do international work because we have a responsibility there'. It was really to pay for our national representation activities. During this 'third phase', we were making money out of national projects and international projects. Those projects were really small scale and not managed very well, and the international activities did not really fit the profile of us as an organisation.

In 2009, he believed COC was in Phase four, in which 'project-funded' international work is seen to be at the core of the organisation's activities. RFSL has similarly accessed development funds from Sida since 1999, including full funding for its cornerstone sexuality rights training programme.

This characterisation of self-interest as aid is not unique to LGBT organisations, of course. In The Postcolonial Politics of Development, llan Kapoor demonstrates how, on the one hand, 'the discourse of aid is constructed as a non-reciprocated gift,' but on the other, 'the discursive practice of aid is also tied to conditionalities, be they economic (tied aid), ideological (neoliberalism), or political (foreign policy objectives)' (Kapoor 2008: 78). What does it mean to view the 'gift' of RFSL's and COC's expertise, knowledge and ability to access resources as a reciprocal act? Foreign aid discourse, Kapoor points out, constructs the donor-recipient relationship such that the donor country - Western, of course - is rich and enlightened.

Its privileged status makes it incumbent upon it to act with kindness and generosity, while its superior wealth and knowhow somehow situates it as an exclusive agent of development. There is more than a tinge of Christianised paternalism here, foreign aid sometimes being associated with good conscience, charity, benefaction, salvation.

(op. cit:: 79)

The recipient country or community, on the other hand, 'is a victim of unfortunate circumstances (of its own making). And it is haplessly dependent on the benevolence and altruism of the Western donor (to which gratitude is owed)' (ibid.). Barbara Heron also points out that there are also many important personal benefits that individuals involved as development workers earn other than financial ones. 'For [white] women like myself,' she says, 'the development context can be a space where we actualise a fullness of subjectivity that we take to be who we truly are, for this is the self we are produced to want to be... [Consequently,] our desire for development, while a manifestation of the helping imperative, can be more accurately understood as a profound desire for the self' (Heron 2007: 156).

The 'rescue' of LGBT people in the Global South, whether by RFSL, COC or the World Bank, also neatly maps into long-standing and powerful teleological narratives which set the 'backward and barbaric' South against 'the progressive and civilised' North. Maja Horn has observed:

The progressiveness (or backwardness) of Latin American countries when it comes to LGBTQ issues and communities tends to be gauged through the presence (or absence) of LGBTQ social movements, political activism and organising around sexual minority rights, and public expressions of gay and lesbian identities.

(Horn 2010: 169) 
Sexuality was as powerful a trope for gauging civility as it was in the colonial era, and so it now remains - except that the evaluation schematic has flipped. Evidence of homosexual sex in African, Asian and Latin American societies was used as evidence of their backwardness and waywardness in colonial times, because colonising European nations were deeply anxious about, and punitively disciplined, sexual desires that challenged hegemonic heterosexuality. The British and other European powers criminalised sodomy and other sexual acts in their colonies, and their laws were incorporated into postcolonial nation-building projects. Following the fall and/or retreat of colonial powers in the 1950s and 1960s, emergent states tasked with 'development' by the newly formed Bretton Woods institutions, became obliged to work towards the kinds of advanced societies of their former colonisers. Not surprisingly, reforms mirrored those of the colonial era. Postcolonial states did not usurp old and imposed colonial measures of civility, like anti-sodomy, but aspired to meet them. Taking charge after winning independence required proof of fitness to lead. Disciplined sexuality was a key component of civility, as M. Jacqui Alexander argues:

Erotic autonomy signals danger to the heterosexual family and to the nation. And because loyalty to the nation as a citizen is perennially colonised within reproduction and heterosexuality, erotic autonomy brings with it the potential of undoing the nation entirely, a possible charge of irresponsible citizenship, or no responsibility at all.

(Alexander 2005: 22-3)

Writing about the Bahamian State as an example of this process, Alexander (2005) and Bedford (2009) both show how it engaged in a programme of 'heteropatriarchal recolonisation' in which the State's peoples were subsequently 'sexualised and ranked into class of good, loyal, reproducing, heterosexual citizens, and a subordinated, marginalised class of noncitizens who, by virtue of choice and perversion, choose not to do so' (Alexander 2005: 46). This ambition of creating 'loyal, reproducing heterosexual citizens' was folded into the development projects that promoted heteronormativity through education, health and economic programmes. As Toni Morrison concluded, 'respectability might well function as debt payment for rescue from incivility and from savagery' (Morrison 1992: vii, cited in Alexander: 14).

The terms of this rescue have now changed. More than 500 years after the 'first encounter' between native and coloniser, the latter's particular and purposeful racialised anxieties about sex still hang over the existence, and inhabits the psyches, of natives' descendants. Recently, however, a new consensus emerged. As more European and North American states have revised sexual regulation laws to legitimise particular forms of homosexual expression and unions (primarily ones that mimic dominant heterosexual forms, such as marriage), it is now other countries' expressed discomfort with that particular form of sexual expression that makes them uncivilised. Massad observes: 'While the pre-modern West attacked the world of Islam's alleged sexual licentiousness, the modern West attacks its alleged repression of sexual freedoms' (2007: 37). In Desiring Arabs, he shows this transition in Orientalist writing and political work, from a 'homosexual paradise' (op. cit.: 176) to the worst place on earth for homosexuals. Supporters of what he terms the 'Gay International's missionary tasks'4 have produced two kinds of literature on the Muslim world to this end:

... an academic literature produced mostly by white male European or American gay scholars 'describing' and 'explaining' what they call 'homosexuality' in Arab and Muslim history to the present; and journalistic accounts of the lives of so-called 'gays' and (much less so) 'lesbians' in the contemporary Arab and Muslim worlds.

The former is intended to unravel the mystery of Islam to a Western audience, while the latter has the unenviable task of informing white gay sex tourists about the region and to help 'liberate' Arab and Muslim 'gays and lesbians' from the oppression under which they allegedly live.

(op. cit.: 162). 
Not just tourists, but now development agents see themselves as having responsibility to take on this burden.

The recent pressure being exercised by Global North governments and organisations to advance sexual rights in the Global South must be understood in relation to this history. Given the great effort extended through the institutionalisation of heteronormativity to demonstrate civility worthy of national sovereignty, it is not surprising, then, that challenges to heteronormativity would be met with aggressive apprehension. Although anti-sodomy laws might have been enacted by colonial powers, and although the pursuit of institutionalised heteronormativity across the Global South has always been linked to colonial history, many political and religious leaders from Global South countries are able to claim them as nationalist projects operating against the sexually liberalising forces of the Global North. That is not to say pre-colonial cultures were not heteronormative, but rather that contemporary iterations of heteronormativity are specifically tied through law to both colonial rule and contemporary formations of geopolitical power. Those religious and political leaders who express homophobic nationalism of course are doing so through piecemeal and careless evaluation - few of them seem to be as concerned about neoliberal market policies, for instance, as Western impositions - but it is important to understand the fuller historical context of their operation. To do so resists characterisation of opposition to LGBT rights in Global South countries as 'cultural' homophobia. For example, India has been subject to the kind of oscillating representations of its sexual politics that Massad makes of the Middle East. Centuries-old depictions of its cultures represent India as a hotbed for same-sex eroticism, but contemporary representations characterise it as a homophobic culture. A much circulated 'Global Homophobia' map produced by The Atlantic revealed that worldwide, most people think India is among the worst places for a homosexual to live. ${ }^{5} \mathrm{~A}$ historical review of the Indian Penal Code (IPC) provides more context to the latter characterisation, however. The IPC was the first comprehensive codified law produced anywhere in the British Empire. Lord Macaulay spearheaded this project, following his appointment as the first Law Member of the Supreme Council of India in 1834. Macaulay reframed old and existing English laws on vagrancy, sex work and buggery to incorporate emergent fears about interracial mixing, homosexuality and bestiality, and presented a draft of the Penal Code in 1837. Prohibitions against sodomy appeared as an act 'against the order of nature' in Section 377 of the Penal Code, under the title 'Unnatural Offences'. The final adoption of the IPC in 1860 resulted in revision of British law itself. In 1861, the 'Offences against the Person Act' dropped the death penalty for the 'abominable crime of buggery', imposing instead the sentence of ten years named in the IPC (Gupta and Long 2008: 20). The IPC also became the model for British colonies' legal systems, including in the Caribbean. ${ }^{6}$ Further, as historically had been the case in Great Britain, antisodomy laws and prohibitions on sex work were packaged with vagrancy laws, revealing the real matter at hand: to mark non-white bodies as impure and dirty, and to emphasise the threat posed by their dirtiness to the superior and morally pure bodies of the imagined English heterosexual.

Rather than accept the racist characterisation of Global South cultures as homophobic - and indeed, which cultures anywhere in the world have never demonstrated social anxieties about same-sex desire? we must also ask: What are the underlying beliefs about 'race', culture, gender, difference, sexuality and civilisation that drive Global North queers' imperative to rescue? Similar to Gayatri Chakravorty Spivak's characterisation of much gender and development work in India as 'white men saving brown women from brown men', a great deal of work on sex rights in the South is configured as 'white queers saving brown queers from brown homophobes' (Spivak 1988: 296-7). In more sophisticated programmes, acknowledgement is made of the colonial roots of anti-sodomy laws in the Global South, most often in the case of former British colonies. Looking at some of the demands made in offers of their 'help' begins to provide some answers. As Massad so powerfully demonstrates is the case with the Gay Internationals' interventions in the Arab world, the 'help' offered/insisted upon toward 'liberation' requires both the evisceration of local histories and experiences and the valorisation of particular, dominant metropolitan, Euro-American expressions of sexual cultures, including sexual identity. When RFSL sets up an international school to train 
LGBT activists from the South, organisers might be genuinely invested in sharing skills they've learned from their own experiences in Sweden, but how can any skills transfer operate in an ahistorical neutral space? Because of the particular and powerful ways in which sexual regulation and sexual practices are always historically and geographically configured and produced, how could any universalising initiative support meaningful and considerate social change?

Because they are often so bereft of a historical consideration of power, 'rescue' initiatives of LGBT people in the Global South have tended to reassure rather than challenge views of Global South cultures as barbaric and under-civilised. Jim Yong Kim's action to halt the World Bank loan to Uganda, for example, was premised in a notion of global community that allies 'civilised people' of the Global North with gays and lesbians in the Global South. This alignment of LGBT people of the Global South with a Global North benevolence and civility might sometimes prove helpful to some who become 'rescued'; however, it does little to generate dialogue between people in the Global South. Explaining its decision to privilege dialogues between heterosexual and homosexual communities over and above alliances and work with Gay International groups, the Trinidad and Tobago LGBT organisation CAISO notes: 'What has distinguished local engagement with issues of sexual citizenship and faith community from the kinds of advocacy for "gay rights" that take place in many other settings is that ours has been a fundamentally nation-building approach' (CAISO 2010). At a Sexual Rights forum held in Trinidad and Tobago in 2010, CAISO co-founder Colin Robinson further elaborated:

Our nation of Trinidad and Tobago... was forged in the fires of overcoming several forms of domination and repression: Colonialism that says your land and decision making do not belong to you. Imperialism that says your resources do not belong to you and you do not think for yourself. Indentureship that says your labour does not belong to you. And slavery that says your body does not belong to you. And, as we know well from the history of miscegenation during slavery, when your body does not belong to you, neither do your sexuality nor your reproduction - they belong to the master. We cannot replace massa [Masters] with husbands; or political leaders; or the state; or laws and policies that say: yes you are free, but we will still tell you what you may do with your free body, with your sexuality, with your reproduction. (Robinson 2010)

Both Robinson's references to the specific historical experiences that shaped contemporary Trinidad and Tobago, and CAISO's stated privileging of engagement between local people provide an alternate framing. It is no longer a matter of 'rescue' from outside; rather than underlining and aggravating divisions between LGBT and heterosexual people in the same place, which serve and reiterate narratives of the 'savagery' of Global South cultures and peoples, the appeal is toward selfreflective community interrogation and engagement. CAISO's approach does not resolve every difficult tension faced in negotiating sexuality rights in postcolonial states (Gosine, forthcoming) but it is a conscious, and productive, departure from the homonationalist and anti-historical inclinations of many international efforts. Its reframing of sexual regulation as a consequence of historical power interrupts dominant narratives of teleological progress and, I believe, most importantly, reshapes potential constituencies of allies in their struggles. For CAISO, the battle for rights is not between the 'civilised world' (including LGBT peoples of the South) versus the backward, straight homophobes of the North, as so many development efforts suggest, but of a confrontation with the trauma of Oppression that has produced social anxiety about homosexuality (cf Gosine, forthcoming). 


\section{Real love}

While 'rescue' missions of LGBT people in the Global South serve homonationalist ends, I would agree that acknowledgment that not all of the 'world's poor' are heterosexual poses a significant challenge to dominant thinking and practice in international development. Heteronormativity persists throughout development programmes, but over the last decade especially it has been troubled, and there are more opportunities to recognise familial and social relationships that are not fully invested in a closed, heterosexual model of procreation and affinity. Fifteen years ago, all development texts or policies implicitly or explicitly demanded and promoted heterosexuality; today, some do not. Still, representations of the sexual desires and lived sexual experiences of people from Global South countries have far to go in capturing and considering their complexity. When I first became interested in research on sexuality issues in development, it was not actually same-sex desire that concerned me but the development industry's representation of heterosexual, reproductive sex between 'Third World peoples'. I was upset about the ways in which people like my parents and the people with whom I grew up in rural Trinidad were understood, like all Third World people, to lack a complex subjectivity. In talks, texts and policies about family planning and control, 'Third World peoples' were described as behaving the same way. The collective poor had reproduced for socioeconomic reasons; no individual had his/her/their own desire. As a child of parents who were always publicly expressive about their love (40 years on, they're still endlessly affectionate); as a nephew who witnessed his aunts risk security and safety in pursuit of their sexual desires; and as someone whose own desires seemed to belong just to me - I found it outrageous that desire was written out of poor people's sexualities. As much as the discursive landscape has changed, and despite the proliferation of work about sex and sexuality, I still find myself looking for those expressions of 'real love', complicated and experienced by people with individually wired desires. By 'real love', I mean to suggest a notion of sexuality that recognises the complexity of desire, one that cannot be explained entirely by identity markers or socioeconomic analysis, one that recognises its myriad conscious, subconscious and unconscious formations and iterations.

As I have said above, for some in the development industry, the 'world's poor' now also includes homosexuals. Due to the greater economic power, travel and visibility of middle and elite classes of the Global South, especially as stagnant Euro-American economies become more dependent on incursions of capital by investors and expertise from the Global South, there appears to be more recognition that the sexual desires and lives of all people are complex. Reviewing two important circulating fictionalised representations of the sexuality of people from the South, I demonstrate the political dynamics and limits of greater representation of sexual diversity in development, and identify the enormous challenges that remain in recognising the complexity, and thus, sheer humanity, of 'the poor'.

The evolution of the character Rajesh ('Raj') Koothrappali in the US sitcom The Big Bang Theory the most watched scripted comedy programme worldwide ${ }^{7}$ - provides a telling example of the move toward greater recognition of the complexity of the sexual lives of people from the Global South. Big Bang is focused on the trials and tribulations of a group of four young scientists who are socially awkward and fascinated by comic books, other kinds of 'geek' culture and an actress who lives across the hall from two of them. The character Raj is a former student from India and who is now a scientist. Between 2007 and 2013, through the first six seasons of the show, Raj was constituted though dominant racialising and sexual tropes that harken back to the colonial era. Echoing colonial renderings of Indian men that were emasculating (Sinha 1995, 1999; Reddy 2003), Raj was symbolically constructed as the most feminine of the male characters who was incapable of speaking to girls. Unlike his friends, he reads Archie comics and enjoys 'chick flicks' like Bridget Jones's Diary and Twilight. Unlike the other men on the show, Raj enjoys preparing decadent gourmet meals and interior design, and has a very close relationship to his small Yorkshire Terrier, 'Cinammon'. Because of these 'feminine' interests, a recurring joke on the show concerns Raj's 
sexuality, as many characters speculate that he is in fact gay. However, Raj's heterosexuality is usually recuperated; he is straight, just the most feminine and most gay of the men. At the end of season six, Raj finally becomes capable of speaking to girls without the aid of alcohol. By this time, viewers of the show have glimpsed enough of Raj's life to know that he is from a very wealthy and welleducated family. By the beginning of season eight, long after every other character on the show has established a serious relationship, Raj at last has one. Raj's evolution over the eight years parallels what has happened to representations of Global South people's sexualities over the last decade. There are more representations of individuated desires in circulation, whether through independent cinema, YouTube, Bollywood or Hollywood productions. As on The Big Bang Theory, however, most of these representations appear to link human complexity to capital worth; Raj becomes a more complex and humane sexual subject after it is established that he and his family possess great material wealth.

A similar process is evident in one of the development industry's more visible and emboldened cultural representations of homosexuality. A video issued by the United Nations in 2014 in support of gay rights perhaps most vividly demonstrates how mainstream, identity-centred politics of LGBT groups in the North are framing sex rights campaigns directed the Global South. The Welcome is a Bollywood-style two-and-a-half minute pop video and marks the first UN Free \& Equal campaign in India. The clip, which in its first five months of availability amassed over 2 million viewings, tells the story of a young man who brings his boyfriend home to meet his family for the first time. The family in the video is clearly positioned as upper/middle-class. The first scene consists of a male decorator hanging lanterns for a party. 'Today, Sir is coming with a special friend,' he says to a telephone. The camera then pans to a wide shot of a decadently styled party area, filled with flowers and silks. Even the dog is wearing a silk shirt. Bollywood actress Celina Jaitley is dressed as she might be for one of her Bollywood roles, in bejewelled sari top and wearing gold jewellery. We then see 'Sir', first through his clothes: his lush, gold-buttoned, velvet blazer, then his argyle socks and leather shoes, which he's seen brushing to a polish. 'Sir' is then seen in his car and by the time he steps out of it, with his also beautiful, well-dressed male partner, there's little doubt about the social location of this family. They could be Rajs. When the family reacts with surprise, Jaitley reassures them with a phrase right out of a fashion advertisement: 'It's a new look, it's a new attitude,' she sings. 'You might wonder where the old way of living has gone, but who is worried about who likes what, as long as in the world of love, two people want to be with each other.' Everyone eventually dances cheerfully in an elaborately decorated room. Closing credits beckon, 'To Stand for Human Rights with the United Nations, Share this Message'.

The Welcome is a vivid demonstration of scholar John D'Emilio's position that gay identities are shaped through capitalism. Drawing on D'Emilio, Rahul Rao argues that capitalism 'enables the expression of sexuality as an aspect of individual personhood by promoting the individuation of wage labour, thereby disrupting traditional family and kinship arrangements,' while at the same time asserting 'an allegiance to heteronormativity in order to reproduce the next generation of workers' (Rao 2014). This process is evident in the way capital permits accessibility to personhood for Raj in The Big Bang Theory and 'Sir' in The Welcome. Their acceptability as sexual beings is framed through the situation of both of them as 'wealthy'. Despite his apparent transgressions of gender, Raj remains fully committed to a heterosexual identity, and of course becomes attached to a female partner. The arrival of 'Sir' and his partner mimics that of a bride and groom, and the closing scene of everyone dancing together seems to reassure viewers that their relationship will pose no threat to existing family structures. Notably, neither 'Sir' nor his partner speak or sing in the video. Far from contesting dominant heteronormative forms,' Rao reminds us, 'a new neoliberal sexual culture seeks inclusion within the protective embrace of the nation precisely by making its peace with state and market.' Because 'LGBT' identities have been constituted through multiple sites of capital exchange, including global media production, HIV/AIDS funding, human rights discourses and travel, he adds, they may be even more ensconced in the imperatives of 
capitalism. 'Although these identities take their place within enormously complex and variegated landscapes populated by older indigenous gender matrices,' Rao explains, 'their disproportionate power and leadership role in those landscapes might render the movements that they lead less antithetical to capitalism than Western queer Marxist utopian texts had hoped' (2014). We may now see images of homosexuality in development texts like The Welcome, but any notion of complex desire - what I call 'real love' - is afforded only to those whom are folded into the aspirations of neoliberal capitalism.

While capitalism has been resourceful for the advance of LGBT rights around the world (Sinfield 2000), the reinvention of people not engaged in exclusively heterosexual acts as 'gay consumers', etc. has important limits. For example, economist Lee Badgett's World Bank-financed costing out of homophobia in India may offer an effective tool for LBGT advocates inside the World Bank and in the broader development industry, but it does make the wellbeing and rights of people not exclusively engaged in heterosexual sex conditional to their market worth. Rao asks: 'What does such an argument do to those not judged to be 'productive' within its terms - the disabled, the illiterate, the unemployed, the elderly, the development-induced displaced, and others who are constitutively unable and/or unwilling to function as good capitalist citizens?' (Rao 2014).

One need not hypothesise about this conditionality, as it is already evident. Development resources on sexuality rights have explicitly demanded adherence to frameworks and terms of sexual identity that are hegemonic in Western Europe and North America. One must adapt the actual names 'gay', 'lesbian', 'bisexual', 'trans' to claim access to funds like the US Global Equality Fund, and be willing to understand sexuality as an identity that one claims. For example, RFSL's main development activity is a training school for sexual rights activists in the Global South. First held in 1999 and fully funded by Sida, RFSL's 'Advanced International Training Programme on LGBT and Human Rights' brings together people from the developing world to complete a set of two training sessions. The first part takes place during three weeks in Sweden and focuses on theoretical and practical components within the field of LGBT and Human Rights. Participants are expected to work with their own projects in their home countries following completion of this first session, and to attend a 'follow-up' week in their region six months later. The introductory notes explain: 'The programme is designed for participants working in organisations or sectors giving them an influence on issues concerning LGBT and human rights.' The workshops are organised such that scholars and activists from the Global North are positioned as the experttrainers and LGBT self-identified activists and workers as participants or informants. For example, in their 2007-8 Asia-focused session, various British, Canadian and Swedish academics led sessions on such topics as 'Basic perspectives on sexuality, gender identity and sexual identity', 'Violations of LGBT human rights' and 'Human rights, international law and founding principles. Protection of LGBT persons' at both the Stockholm leg of the training as well as the 'Asia' leg held in Bali, and partnered with Indonesian LGBT organisation Arus Pelangi. Where the training sessions led by Euro-Americans were instructive about theorising sexuality, the few led by Arus Pelangi were geared as information sessions for visitors, describing their activities and challenges. Similarly, Ashley Currier's study of the work of African LGBT group Behind the Mask, which has received funds from several development agencies - including the World Bank - for some of its work, revealed donors' emphasis on 'visibility' to accede support. Currier points out that 'grassroots organisers operating unofficially or on a small scale usually require funds to sustain their efforts, and they market themselves to obtain funds.' Consequently, organisations like Behind the Mask alter their public visibility to match a donor's programmes and ideals. Such strategising around visibility, she says, 'may involve reframing a donor's message in a way that resonates with donors, for instance, by using language that equates LGBTI [Lesbian, Gay, Bisexual, Transgendered and Intersex] rights with human rights or by (over)emphasising the local cultural, social and political obstacles that organisations face' (Currier 2010: 155). Currier argues for a better understanding of 'how visibility works' instead. 'The choice for LGBTI persons to become visible may be a luxury in tolerant 
sociopolitical circumstances,' she says, while 'invisibility may be a necessity and perhaps a negative consequence, as the choices for disclosing their alternative sexual and gender identities may be limited for LGBTI persons' (op. cit.: 156). She also asks: 'What happens after LGBTI persons become visible? Does the performance of visibility end with a permanent state of visibility? (op. cit.: 158). Currier concludes, 'LGBTI public visibility may be a political victory in North America and in Western Europe, but regarding the concept only as an accomplishment obscures the processes by which LGBTI persons elsewhere emerge publicly, the obstacles they face in so doing, and their decisions to become visible or to eschew visibility' (op. cit.: 159). ${ }^{8}$

Conditionality has serious consequences. Massad, who laments that the rise of a sexual identity discourse has produced 'homosexuals, as well as gays and lesbians, where they do not exist, and represses same-sex desires and practices that refuse to be assimilated into its sexual epistemology,' reveals how the imposition of these identities has created serious consequences for those most vulnerable to state and social violence (Massad 2007: 163). ${ }^{9}$ On 11 May 2001, police raided a boat cruise on Egypt's Nile River, and arrested 55 people, 34 of whom were on the boat at the time of the arrests. ${ }^{10}$ The arrests garnered global attention and became the central focus of international advocacy campaigns and a much-circulated documentary, Dangerous Living: Coming Out in the Developing World. Massad points out that:

It is not same-sex sexual practices that are being repressed by the Egyptian police but rather the sociopolitical identification of these practices with the Western identity of gayness and the publicness that these gay-identified men seek.

(op. cit.: 183)

International gay activists ignored this distinction, Massad says, resulting in advocacy campaigns that ultimately served two constituencies: themselves and social conservatives in Egypt who called for new disciplinary measures against sexual freedom in response. Massad puts blame for the Egyptian government's repressive campaign on gay rights activists. 'Despite the overwhelming evidence that gayness, as a choice, is proving to bring about more oppression, not "liberation", and less sexual freedom rather than more for Arab men practicing same-sex contact,' he concluded, 'the Gay International is undeterred in its missionary campaign' (op. cit.: 184). Rebuking an American Arab gay activist's characterisation of the Queen Boat raid as 'our own Stonewall', Massad pointed out:

The reaction of the drag Queens at the Stonewall bar was indeed significantly different from the reaction of the men at the Queen Boat discotheque; the latter... denied being 'homosexual' or 'gay'... Also, not only did these men not seek publicity for their alleged homosexuality, they resisted the very publicity of the events by the media by covering their faces in order to hide from the cameras and hysterical public scrutiny.

(op. cit.: 184-5)

'These,' he concludes, 'are hardly manifestations of gay pride or gay liberation' (op. cit:: 184-5). More importantly, the intervention of the Gay International lobby resulted in a worse situation for men who have sex with men in Egypt. Massad notes that harassment increased following the Queen Boat case, with increased police surveillance and arrests of people suspected of 'debauchery' and a report by Human Rights Watch claimed that Egyptian law enforcement officials took it as 'an incentive to increasing rigor, or even a route to career advancement' (op. cit.: 185).

Deployment of an uncritical sexual identity-politics has also produced other dubious results that are not always helpful to intended subjects of aid. For example, India's gender bending hijra population has become increasingly visible in the past decade through HIV/AIDS discourses and intervention programmes. This recognition has brought new resources directed at the population. But as Jyoti Puri (2010) points out, it has also meant heightened surveillance and scrutiny of hijras, especially by NGOs with ties to the state as well as international donors and agencies. Along with 
non-transgendered women, sex workers and men truck drivers, hijras are becoming the most maligned groups in the HIV/AIDS discourse in India, Puri says. Hijras have also been framed as 'transgender' in international discourses of sexuality, but such a reading might not actually reflect the way hijras see themselves. Many human rights organisations hailed the 14 April 2014 ruling by the Indian Supreme Court to recognise a third gender. The case was mounted largely on the basis of the long-standing history of hijra in India. 'Recognition of transgenders as a third gender is not a social or medical issue but a human rights issue,' said Justice K.S. Radhakrishnan, who headed the two-judge Supreme Court bench. 'Transgenders are also citizens of India, the court declared, and they must be 'provided equal opportunity to grow. The spirit of the Constitution is to provide equal opportunity to every citizen to grow and attain their potential, irrespective of caste, religion or gender' (BBC News 2014). However, within a few days, new challenges to the application of this notion of identity were made. A number of transgender women viewed the adoption of a third category would increase discrimination against them. 'When I was 14, I chose to become a woman from a man. I am still fighting to be accepted as a woman. I want to build a respectable livelihood as one. I don't want to be a "other" gender person', said Pavithra, now 32 (Avani 2014). Listed as Female on her Voter's ID, she doesn't want it changed it to 'Others' because 'It takes away my identity'. Claiming sexual identity provides a recognisable and familiar basis for action; in the Supreme Court case on transgender rights, the judges asked the government to treat them in line with other minorities officially categorised as 'socially and economically backward', to enable them to get quotas in jobs and education. However, as Pavithra's objection makes clear, it may not reflect the desires or interests of those on whose behalf actions are made.

As demonstrated in The Welcome, prioritisation of same-sex marriage has also evolved as a condition for support. In the UN video, it is acceptance of the coupling of 'Sir' and his partner that is judged to be their only concern. The couple seems to have all material needs fulfilled; they just can't get married. Over the last decade same-sex marriage rights have gained more attention than any other issue related to homosexuality. Same-sex marriage has become the aspirational 'end game', the ultimate victory for normalisation of same-sex desire. But passionate critiques of gay and lesbian organisations' championship of marriage have been made. For some, gay marriage represents assimilation into heteronormativity and a rejection of a politics of queer liberation, while others view it as the extension of the neoliberal state, which depends on privatised capital, available through marriage, to access health care and other basic supports. Co-founder of US-based organisation Against Equality, Yasmin Nair argues:

It's hard to see how fighting for inclusion in the benefits-distribution system that is marriage will in any way challenge the legitimacy of that system rather than just reinforce it. Under the guise of social progressivism, gay marriage is the ultimate neoliberal shell game, a sleight of hand that obscures the real inequalities faced by those who won't or can't marry into economic stability or wealth.

(Nair 2014)

Feminists long critical of marriage are perplexed by the high priority given to it by gay and lesbian movements. 'The problem with gay marriage,' stated noted feminist Germaine Greer, 'is not the gay bit but the marriage bit. In a sane world, heterosexuals would be demanding the rationalisation of marriage or, better, its abolition' (Greer 2013). She also pointed out that less than 50 years ago co-habiting heterosexuals who tried to live together would find themselves summarily evicted, 'the locks changed and their property dumped in the street by the landlord, their deposit forfeited, because they had used the premises for an immoral purpose. We pushed as hard then for the right to remain unmarried as they are fighting now for the right to be married' (ibid.).

Foregrounding marriage has also pushed other concerns off the table. At a presentation in Toronto in 2014, Helen Kennedy, Executive Director of Canada's national LGBT rights organisation, Egale, said it was a mistake to believe that same-sex marriage was the ultimate victory, pointing to higher 
rates of hate crimes targeting LGBT people, and high rates of suicide and poverty. One in five homeless youth in Canada was LGBT, she pointed out. In the USA, queer organisation Dark Matter started tweeting the hashtag \#NotProud in the run-up to the New York Pride parade as a challenge to the mainstream gay movement's politics of normalisation. The \#NotProud hashtag followed such tweets as:

'43\% of hate violence incidents against LGBTQ people happened in private residences';

'37\% of LGBTQ survivors of violence report hostile attitudes when reporting to the police';

'72\% of LGBTQ homicide victims were transgender women';

'89\% of all LGBTQ homicide victims in 2013 were people of color';

'there was a 21\% increase in reports of physical hate violence against LGBTQ people in 2013'; and

'when we discuss sex as if it occurs outside of material conditions of poverty\&violence. who's arrested next door while u have fun?'

While these debates have mostly been confined to the Global North, the foregrounding of marriage in identity-centred gay politics is already having repercussions in the South. In Trinidad and Tobago, for example, Robinson has found that he has had to spend a lot on energy assuaging fears about gay marriage at the expense of highlighting more pressing needs for the local LGBT community. 'Marriage easily shuts down reasoning among otherwise decent people about LGBTI inclusion,' he says, 'and it's not an important priority expressed by people we work with, and tends to have more interest among people with more privilege for whom discrimination, violence and access to justice are solved by class protections' (interview, June 2014)."1

\section{A call for complexity}

I believe that the most critical demand one can make of development actors engaged in pursuit of sexual rights at this juncture is for more complexity. That demand would include a deeper historical analysis, including of homophobia in the Global South, and a more cautious consideration of normalisation strategies that incorporate same-sex desire into heteronormative institutions. Interestingly, attention to same-sex desire has forced recognition that desire exists among the poor outside of socioeconomic interests and hegemonic cultural demands. But in many ways, the challenge remains the same: recognition of the complex subjectivity and dignity of development's imagined subject of 'the poor'. The misleading but determined adherence to an unproven framework of stable heterosexual and homosexual identities is an affront to this complexity as are the endless representations of peoples of the Global South as essentially homophobic.

All sexual desires are complex, unwieldy and messy. Neither innocent nor controllable by our conscious, each person's sexual desires are formed through her/his/their life experience. They also shift, though rarely in ways we can consciously identify, much less entirely control. ${ }^{12}$ While the arrival of homosexual/queer/LGBT subjects in international development has offered up more categories of sexual identity, it has not begun to grapple with the messiness of desire itself. Unlike most of my peers in the field, I prefer talking about 'love' and 'desire' over sex, not due to some kind of naïve allegiance to a notion of sexual morality, but rather because their very abstractness, their varied interpretations and their broader potential to include a range of physical, emotional, material and 
psychic matters make it a more honest characterisation of what is at hand and what is at stake in negotiating erotic autonomy at this moment. The primary task, for me, is less about finding the most 'effective' strategy or refining terms of identity or exchange, but in challenging ourselves to really see my parents, the people I grew up with, and all of those 'simple', nameless, functional 'poor' subjects of development as fully, complexly human, with social environments and histories and individual experiences and feelings, which demand more ethical and respectful engagement. 


\section{Notes}

1 By 'development' I mean the discursive and institutional practices articulated and enacted through multilateral, government, private, community and other organisations engaged in projects that structure North-South economic, social and political relationships.

2 The 'development industry' is an unstable amalgam of many different actors often working in support of, sometimes against, each other's interests: governments, international agencies like the World Bank and International Monetary Fund, NGOs of feminists, environmentalists, human rights activists or religious fundamentalists, health institutions, social service workers, economists, doctors, lawyers, educators and more.

3 See www.peuglobal.org/2013/06/04/the-global-divide-on-homosexuality/

4 Citing the IGLHRC's mission statement to 'protect and advance the human rights of all people and communities subject to discrimination or abuse on the basis of sexual orientation, gender identity, or HIV status', Massad characterises 'these missionary tasks, the discourse that produced them, and the organizations that represent them' as constitutive of the 'Gay International' (2007: 161)

5 See www.citylab.com/politics/2014/02/global-map-homophobia/8309/

6 The Straits Settlement Law of in 1871, covering territory that today encompasses Singapore, Malaysia and Brunei, effectively duplicated the IPC. Between 1897 and 1902, administrators applied the IPC in Britain's African colonies, including Kenya and Uganda. By the time criminal codes were established in Trinidad and Tobago, Guyana, Jamaica and Barbados, they had also incorporated clarifications set in English law about the meaning of 'natural offences', such as a 1885 revision that punished 'Any male person who in public or private commits or is a party to the commission of or procures or attempts to procure the commission by any male person of any act of gross indecency with another male person' (Gupta and Long 2008: 20). 'Gross indecency' was a broad offence designed to include virtually all kinds of non-penetrative sexual acts between two men (op. cit: 21).

7 According to data compiled by Eurodata TV Worldwide; see also http://uproxx.com/tv/2014/01/big-bang-theory-officiallypopular-sitcom-world/

8 A politics of 'visibility' is so hegemonic that even Currier's critique is intransigent in its valorisation of and assumed universal desire for visibility of sexual identity. She appears interested in teasing out how 'visibility' works, not opening up a conversation about whether it should even be a goal, and what 'coming out' makes necessary: adoption of a sexual identity.

9 In Desiring Arabs, Massad demonstrates how non-Western forms of sexuality are simultaneously erased and reconfigured through dominant Euro-American identity practices in the Middle East. Disputing a claim by one Western scholar that 'Arabic synonyms for "to fuck" have no form of reciprocity', Massad notes, 'both classical and modern Arabic have the very "tanayaka", which does indicate reciprocity as when two people "yatanayakan" meaning that they are "fucking each other"' (2007: 170). This confusion over reading and representing the unstable sexual landscape of Arab societies dates back to colonisation, he says, with the subsequent invention of Arabic words to fit European frameworks:

The word 'jins', for example, meaning 'sex,' emerged in Arabic sometime in the earlier part of the twentieth century carrying with it not only its new meanings of a 'biological sex' and 'national origin,' but also its old meanings of 'type,' 'kind' and 'ethnolinguistic origin,' among others. The word in the sense of 'type' and 'kind' has existed since time immemorial and is derived from the Greek 'genos.' As late as 1870, its connotation of 'sex' had not yet taken place. (op. cit.: 171)

Similarly, 'jinsiyyah' was coined by translators of Freud to mean sexuality, as were 'mithliyyah' invented to mean homosexuality and 'ghayriyyah', heterosexuality (op. cit.: 172).

10 Women and European and American men were released immediately, as were three Egyptian men 'found to be the sons of "prominent" people' (Massad 2007: 181). The official charges brought against the men were of 'offending religion' (op. cit.: 182).

11 See also Oosterhoff et al. (2014).

12 For more on desire in development, see Kapoor 2005 and 2014 


\section{References}

Adams, Vincanne and Pigg, Stacy Leigh (eds) (2005) Sex in Development, Durham NC: Duke University Press

Alexander, M. Jacqui (2005) Pedagogies of Crossing: Meditations on Feminism, Sexual Politics, Memory, and the Sacred, Durham NC and London: Duke University Press

Avani, Tanya (2014) 'Transgender Allowed to Vote as a "Third" Sex, "But I am a Woman not an 'Other'", video, www.loksabhaindia.org/en/photographers/avani-tanya/transgender-al-voto-cometerzo-sessoma-sono-una-donna-non-un-altro.html (accessed 12 October 2014)

BBC News India (2014) 'India Court Recognises Transgender People as Third Gender', 15 April, www.bbc.co.uk/news/world-asia-india-27031180 (accessed 11 February 2015)

Bedford, Kate (2009) Developing Partnerships: Gender, Sexuality, and the Reformed World Bank, Minneapolis MN: University of Minnesota Press

CAISO (2010) 'We Take a Pride in our Liberty', Gspottt, blog, 17 October,

http://gspottt.wordpress.com/2010/10/17/we-take-a-pride-in-our-liberty/ (accessed 20 October 2014)

$\operatorname{COC}$ (n.d.) 'Fighting for Acceptance All Over the World', COC, www.coc.nl/engels (accessed 18 October 2014)

Cornwall, Andrea and Jolly, Susie (2009) 'Sexuality and the Development Industry', Development 52.1: $5-12$

Cornwall, Andrea; Correa, Sonia and Jolly, Susie (2008) Development with a Body: Sexuality, Human Rights and Development, London: Zed Books

Currier, Ashley (2010) 'Behind the Mask: Developing LGBTI Visibility in Africa', in Amy Lind (ed.), Development, Sexual Rights, and Global Governance, New York: Routledge: 155-68

Gosine, Andil (forthcoming) 'CAISO, CAISO: Negotiating Sexualities and Nationalisms in Trinidad and Tobago', Sexualities

Gosine, A. (2010a) 'Non-white Reproduction and Same-sex Eroticism: Queer Acts Against Nature', in C. Sandilands and B. Erickson (eds), Queer Ecology, Bloomington IN: Indiana University Press

Gosine, A. (2010b) 'The World Bank's GLOBE: Queers In/Queering Development', in Amy Lind (ed.), Development, Sexual Rights and Global Governance, New York: Routledge

Gosine, Andil (2004) Sex for Pleasure, Rights to Participation and Alternatives to HIV/AIDS: Placing Sexual Minorities in Development, IDS Working Paper 228, Brighton: IDS

Greer, Germaine (2013) 'Gay or Not, Nuptials are Now Divorced from Sense', The Guardian, www.smh.com.au/comment/gay-or-not-nuptials-are-now-divorced-from-sense-201304182i14o.html\#ixzz340A25KsY (accessed 23 January 2015)

Gupta, Alok and Long, Scott (2008) This Alien Legacy: The Origins of 'Sodomy' Laws in British Colonialism, New York: Human Rights Watch 
Heron, Barbara (2007) Desire for Development: Whiteness, Gender, and the Helping Imperative, Waterloo ON: Wilfrid Laurier University Press

Horn, Maja (2010) 'Queer Dominican Moves: In the Interstices of Colonial Legacies and Global Impulses', in Amy Lind (ed.), Development, Sexual Rights and Global Governance, New York: Routledge

Kapoor, Ilan (2014) 'Psychoanalysis and Development: An Introduction', Third World Quarterly 35.7: 1117-19

Kapoor, Ilan (2008) The Postcolonial Politics of Development, London: Routledge

Kapoor, Ilan (2005) 'Participatory Development, Complicity and Desire', Third World Quarterly 26.8 1203-20

Kennedy, Helen (2014) Presentation at the Toronto International Film Festival screening, 1 June, Toronto

Kim, Jim Yong (2014) 'Jim Yong Kim: The High Costs of Institutional Discrimination', Washington Post, Opinions, 27 February, www.washingtonpost.com/opinions/jim-yong-kim-the-high-costs-ofinstitutional-discrimination/2014/02/27/8cd37ad0-9fc5-11e3-b8d8-94577ff66b28_story.html (accessed 11 February 2015)

Lind, Amy (2010) Development, Sexual Rights and Global Governance, London: Routledge

Massad, Joseph A. (2007) Desiring Arabs, Chicago: University of Chicago Press

Murray, David A.B. (2009) 'Homo Hauntings', in David A.B. Murray (ed.), Homophobias: Lust and Loathing across Time and Space, Durham NC: Duke University Press

Nair, Yasmin (2014) 'The Same Sex Marriage Trap', In These Times, 3 February,

http://inthesetimes.com/article/16132/the_same_sex_marriage_trap (accessed 12 October 2014)

Oosterhoff, Pauline; Waldman, Linda and Olerenshaw, Dee (2014) Literature Review on Sexuality and Poverty, Brief Supporting Evidence Report 55, Brighton: IDS

Oswin, Natalie (2007) 'Producing Homonormativity in Neoliberal South Africa: Recognition, Redistribution, and the Equality Project', Signs 32.3: 649-69

Puar, Jasbir (2007) Terrorist Assemblages: Homonationalism in Queer Times, Durham NC: Duke University Press

Puri, Jyoti (2010) 'Transgendering Development', in Amy Lind (ed.), Development, Sexual Rights and Global Governance, New York: Routledge

Rao, Rahul (2014) 'Staying Positivist in the Fight against Homophobia', Sexuality Policy Watch 14, July, www.sxpolitics.org/?p=9411 (accessed 13 October 2014)

Reddy, Gayatri (2003) "'Men” Who Would be Kings: Celibacy, Emasculation, and the Re-production of Hijras in Contemporary Indian Politics', Social Research: An International Quarterly 70.1: 163-200

RFSL Sweden (2008) 'International Development Strategy 2008-2010', Stockholm: RFSL Sweden 
Robinson, C. (2010) 'Respecting the Right to Freedom of Thought, Opinion, and Expression of One's Sexuality', Gspottt, 22 March,

http://gspottt.files.wordpress.com/2010/03/caiso_ippfsexualrights.pdf (accessed 21 October 2014)

Sinfield, Alan (2000) Gay and After, London: Serpent's Tail

Sinha, Mrinalini (1999) 'Giving Masculinity a History: Some Contributions from the Historiography of Colonial India', Gender \& History 11.3: 445-60

Sinha, Mrinalini (1995) Colonial Masculinity: The 'Manly Englishman' and the 'Effeminate Bengali' in the Late Nineteenth Century, Vol. 1, Manchester: Manchester University Press

Spivak, Gayatri Chakravorty (1988) 'Can the Subaltern Speak?', in Cary Nelson and Lawrence Groosberg (eds.), Marxism and the Interpretation of Culture, Champaign IL: University of Illinois Press 
First published by the Institute of Development Studies in March 2015

(C) Institute of Development Studies 2015

ISBN: 978-1-78118-218-5

The content of this publication may be reproduced and disseminated for non-commercial purposes, provided that reference is made to the name(s) of the author(s), and to the original publication in the following style:

Gosine, A. (2015) Rescue, and Real Love. Same-sex Desire in International Development, Brighton: IDS

These licensing conditions must also apply in the case of further reproduction.

For mail order sales or subscription details please contact:

Communications and Engagement Unit, Institute of Development Studies,

Brighton BN1 9RE, UK

Tel: +44 (0) 1273915637 Fax: +44 (0) 1273621202

E-mail: bookshop@ids.ac.uk

Web: www.ids.ac.uk/ids/bookshop

IDS is a charitable company limited by guarantee and registered in England (No. 877338)

Photo: Video Still from (Made In Love), Andil Gosine, 2013. 
Fifteen years ago, there was little space within international development policy circles within which we could talk about sexual rights, desire or pleasure. Homosexuality as a topic of debate was routinely invisible and development agencies and international non-government organisations collectively struggled to see the relevance of lesbian, gay, bisexual, transgender, intersex and queer (LGBTIQ) issues within their broader mandates.

This publication examines the rise of LGBTIQ rights within development and asks how the terms of debate have shifted so much that the industry's most powerful multilateral institution and champion of neoliberal capitalism, the World Bank, is advocating protection rights for sexual minorities. The author focuses upon the growth in interest and financial resources towards the rescue of non-heterosexual people from homophobia in Global South countries and the problematic rise in homonationalism. More encouragingly, he also explores how communities within developing country contexts have challenged rigid heteronormative conceptions of love, desire and affection. 